\title{
Questions to the Past That Resonate in the Present
}

\author{
CHARLES R. SCRIVER
}

\begin{abstract}
DeBelle Laboratory for Biochemical Genetics, McGill University-Montreal Children's Hospital Research Institute, Montreal, Quebec, Canada H3H IP3
\end{abstract}

An appropriate place to begin is with Kierkegaard's statement that life can only be understood backward but it must be lived forward. Appropriate for a centennial symposium, don't you think? Accordingly, I will use the occasion to pose questions to the past that resonate in the present, as someone said in a discussion of the role of history. I tried to do something similar in my presidential address to the SPR (1) when the topic was genetics. It worked then. Perhaps it will again.

If we review historical events in genetics just preceding the birth of the American Pediatric Society (Table 1), we find that they retain some interest for us today, although genetics was not a word in use then [it was coined by Bateson (2)]. The quarter century preceding the founding of our Society was an exciting time for biologists (Table 1).

Darwin and Mendel were at work; Down and Huntington described the diseases we know by their names; Meischer discovered the "nucleoprotein" that would yield DNA; and there was Galton (Darwin's cousin). Galton is remembered for, among many things, an interesting experiment on the efficacy of prayer. He recognized that, every week in the realm, the people most prayed for by the Church of England were the royals; the customary prayer was for a long life. He measured longevity through several generations of royalty and compared it to controls. $\mathrm{He}$ showed that the anointed ones did not live longer than their controls!

We laugh at this now and yet on the front page of yesterday's paper I read a report of parents who had prayed for their child's health rather than treat her disease. Their child went on to die of meningitis, deprived of the benefits some past members of this Society gave us in the form of treatment for that child's disease. With all our knowledge and opportunity, we are still, at times, irrational people.

Many of the developments in genetics (Table 1) appear, with hindsight, to have been dramatic and exciting for their times: knowledge about mitosis, cell division, and meiosis; development of the concept that the chromosome, chromatids, and the "threads" that could be seen at the time were the bearers of inherited factors that determined phenotypes of individuals. When we look back on them, we find these to be brilliant achievements for the times, supposedly unsophisticated by present standards. A better understanding backward could help us to be more humble as we live forward.

The social forces and agencies that molded and supported the great investigators of the past are worth knowing. Are their counterparts in place today? Perhaps the Pediatric Investigatorship Program of this Society is one. I hope so. Joseph Goldstein talked about PAIDS (Paralyzed Academic Investigator Disease Syndrome) in his presidential address to ASCI (3). He described the junior professor/investigator who starts out with promise and ultimately fails because he is not prepared to do the science of today. He offered a prescription (training in depth) to avoid PAIDS and he illustrated its efficacy with biographical sketches of three scientists, each born or working during the early years of our own Society.

The noteworthy age- 100 years-of the American Pediatric Society introduces my next subject. Living organisms have a beginning (a birth), a period of development, one of maturity, and they have an end. Five biologic events are necessary and sufficient for all organisms: division, development, movement, communication-and death. Let's not dwell today, as a collective, on the fifth event. But as individuals, we would do well to think about it in private terms and also, as pediatricians who know that "in my beginning is my end" (4).

Darwin and Malthus recognized the importance of a finite lifespan for living systems. But do we think much about the fact that a finite life-span seems to be a dominant phenotype, that immortality is recessive, and that abbreviated longevity was once mostly stochastic, whereas in developed societies like those of Europe and North America an early death is now likely to be predisposed through inherited factors? Genes propose, but experience disposes. The century of the APS contains a segment when the informational system that proposes the events of life was disclosed. The names of those who gave us genes and DNA are familiar: Sutton, Morgan, Avery, MacLeod, McCarty, Beadle, Tatum, Watson, Crick, and others. Meantime, other things were happening to improve the processes of living that dispose of us. They were mainly the achievements in public health, the knowledge of how infective agents do their dirty work, and social engineering.

Sometimes the knowledge base upon which these developments took place was different from that which we traditionally hold to be true. Take, for example, the eradication of smallpox-a major achievement in the lifetime of this Society, mentioned by our president in his address, and a field of endeavour for several members of the APS. Smallpox eradication began almost two centuries ago as a local practice-not a theory-in East Anglia. Practitioners believed that innoculation protected persons. Their practice was shown to be useful and was promoted not just by medical practitioners but also by the clergy from the pulpit as a useful benefit on earth. In due course came empirical vaccination, then theory and knowledge about the immune response, and, in turn, detailed knowledge about the viral cause of smallpox. Carefully made observations and practice first, then theory, then knowledge were the bases of today's smallpox-free world. These endeavours and others like them improved human life expectancy greatly during the century of APS. Therefore, it is of interest to examine the human mortality profile in a population such as ours in North America in the 1980s.

When we plot age-specific mortality by 5 -y intervals, we obtain the relationship shown in Figure 1. Mortality is high in the perinatal period (we all know that!), it declines in childhood, reaches a nadir in puberty, then rises exponentially beginning in early adulthood. It follows that if public health, medicine, and society as a whole have so much improved living conditions and reduced harmful experiences (relative to earlier times), yet we 
Table 1. Genetics in quarter-century before founding of APS

\begin{tabular}{lll}
\hline 1958 & Darwin & Origin of species; natural selection \\
$1865 / 66$ & $\begin{array}{l}\text { Mendel } \\
\text { Down }\end{array}$ & $\begin{array}{l}\text { Inherited factors determine properties } \\
\text { A syndrome ("Mongolism") }\end{array}$ \\
1868 & Meischer & Nucleoprotein \\
1869 & Galton & Nature and nurture; twin method \\
1872 & $\begin{array}{l}\text { Huntington } \\
\text { Galton }\end{array}$ & $\begin{array}{l}\text { Describes the disease } \\
\text { Efficacy of prayer? }\end{array}$ \\
1873 & $\begin{array}{l}\text { Schneider } \\
\text { Cell division (mitotic) (Flemming 1879, } \\
\text { the process) (Flemming 1882, "mito- } \\
\text { sis," the term) }\end{array}$ \\
1879 & $\begin{array}{l}\text { Flemming } \\
\text { Arnold }\end{array}$ & $\begin{array}{l}\text { "Chromatids," "chromatin" } \\
\text { Human mitotic chromosomes }\end{array}$ \\
1882 & Flemming & Human chromosomes; "mitosis" \\
1883 & $\begin{array}{l}\text { Van Beneden } \\
\text { Roux }\end{array}$ & $\begin{array}{l}\text { Meiotic division } \\
\text { Nuclear filaments/hereditary factors }\end{array}$ \\
& $\begin{array}{l}\text { Boveri } \\
\text { Waldeyer }\end{array}$ & $\begin{array}{l}\text { Centriole } \\
\text { "Chromosome" (= Roux's filaments) }\end{array}$ \\
\hline
\end{tabular}

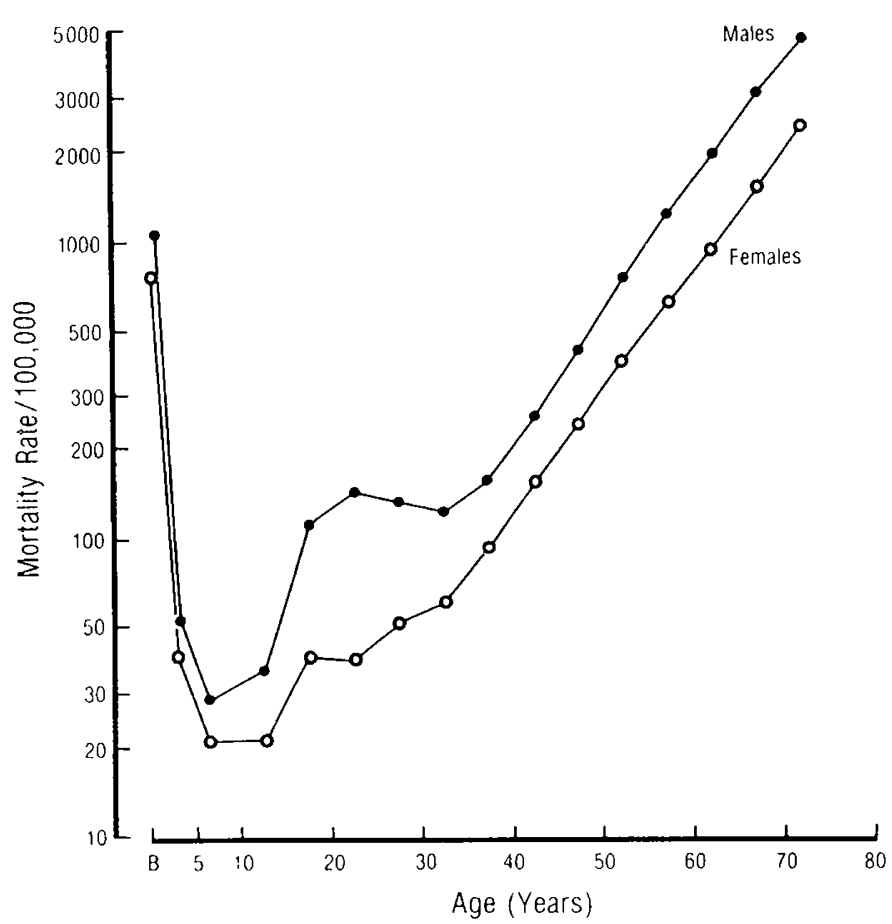

Fig. 1. Age-specific mortality rates (5-y intervals), Canada, 1981 (4).

continue to encounter disease and to die prematurely, then the heritability - the relative importance of genetic causes-of those diseases and deaths has increased whereas their collective incidence has been decreasing. This has been happening during the 100 years of APS existence; accordingly, it is appropriate that the opening theme of this centennial celebration is about genetics.

The downward limb of postnatal mortality represents natural selection at work and it is of interest to pediatricians. But what about those premature deaths in adulthood? Are they of any interest to pediatricians? Medical geneticists say yes, because the child is father/mother to the man/woman (In my beginning is my end). Pediatricians want to be alert to the positive (and
Table 2. Relative risk of mortality in adoptees (when parent died before age 50 y of same disease)

\begin{tabular}{lccc}
\hline & \multicolumn{3}{c}{ Parent } \\
\cline { 2 - 4 } Cause $^{*}$ & Biologic & Adoptive & $p$ value† \\
\hline All & 1.71 & 0.71 & $<0.01$ \\
Natural & 1.98 & 0.96 & $<0.01$ \\
Infection & 5.81 & 0.73 & $<0.001$ \\
Vascular & 4.52 & 3.02 & $<0.001$ \\
Cancer & 1.19 & 5.16 & $<0.05$ \\
\hline
\end{tabular}

* For those in a group of adoptees $(n=960)$ who died $(n=226)$ of disease at $16-68 \mathrm{y}$; rate for concordant causes then ascertained in parents (columns 2 and 3).

† Significance of the difference in relative risks for biologic and adoptive parents assessed by the Proportional Hazards Regression Model (Adapted from Ref. 7)

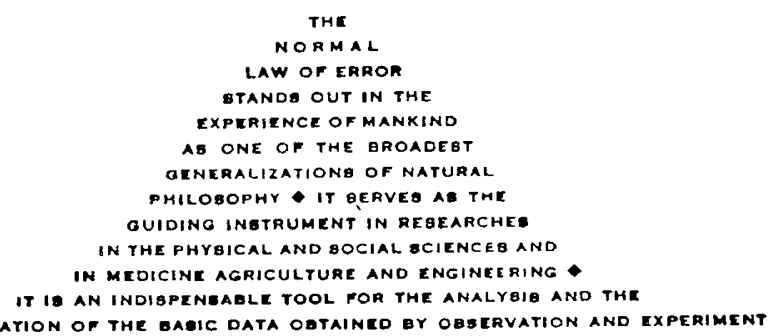

Fig. 2. A novel visual presentation of the normal distribution of metrical biologic values (8).

negative) family history and the age at onset of disease in the family; a theme Barton Childs and I have addressed elsewhere (5). In brief, the earlier the age at onset of the common multifactorial diseases, and the more often the family history is positive for the disease, the more likely there is to be an important genetic determinant of that disease segregating in the family at risk.

It is a theme Sir Archibald Garrod developed in his second book, The Inborn Factors in Disease, published in 1931 (6). The book is about "diathesis" by which Garrod meant inherited susceptibility (or resistance) to disease, and manifest in the "chemical individuality" of the individual. Garrod's book is brilliant in its insights but it failed to have an effect on medical thinking for two reasons: the heritability of disease was low at the time it was written and physicians weren't very interested in "diathesis". And there wasn't much to be done with such an hypothesis-no way to translate it into medical practice and the prevention or avoidance of disease (nothing equivalent to an immunization procedure). However, both of these contexts have changed greatly since 1931 -namely in the second half-century of the APS. First, the heritability of disease has risen and socalled diathesis is important now. Second, the legacy of all that knowledge about genes and DNA, to which I referred earlier, is molecular genetics and in particular DNA diagnostics; one now has the ability to trace and "see" mutant genes in families and persons at risk. All of this has profound implications for the practice and teaching of medicine, notably in pediatrics.

We tend today not to be very interested in history. Life is now, and the Me/Now Generation has little patience for the past. But if one has genes that influence future health and well being, and if they came through events that are past history, perhaps one should be interested in the ethnic and demographic history that shaped one's family.

Take Norwegian migrations, for example. Migration brought Paul Quie's ancestors to Minnesota. Since 1820, Norwegian emmigrants have become as numerous as the total population of that country in that year. Meantime, they have spread their genes into the American population. Some of those genes are determinants of qualities we admire, but some are causes of diseases such as phytanic acid oxidase deficiency (Refsum dis- 
ease) and hereditary tyrosinemia-diseases we would prefer our children not to have!

I am not trying to provoke laughter at our president's expense. I am merely saying something that is true, in its own way, about everyone in this auditorium. We all have biologic and cultural histories that may explain our morbidity and mortality.

This point of view implies that the proper focus in medicine is the patient with the disease, which is something different from the disease the patient has. If I could put that thought into the context of this morning's session on genetics, I imagine we feel very comfortable with Dr. Rosenberg's talk and we cheer to the rafters his evidence of cures for genetic disease because the emphasis, in the final analysis, is on the disease the patient has. Of course, Lee was sensitive and careful to let us know something about three of his patients with particular diseases. But we liked his vignettes because they were good news. Yet, to put the emphasis on cure - and few genetic diseases can be cured at the present time-is different from anticipating and explaining who has or will have the disease and what measures there are to prevent or avoid it.

I want now to pick up a theme introduced by Barton Childs, to weave it into the idea that "in my beginning is my end" (4) and to nail down the viewpoint that pediatricians deal increasingly with genes that determine disease not only in their patients, but in the children who will become adults. Pediatricians deal with people who are living forward.

Sørenson and colleagues recently published a paper (7) reporting the relative risks of mortality for various forms of disease in adoptees. The study was done in Denmark where such work is greatly facilitated by excellent registers of adoptees, their biologic parents, and the adoptive parents. I believe the study is a harbinger of things we want to know in medicine. The Danish workers showed (Table 2) that the relative risk of having a disease (and of dying with it prematurely by age 50) was generally and significantly greater for the adoptees if a biologic parent had the same disease than if an adoptive parent had it. The findings were true for all natural causes of death taken together (versus accidents, etc.) and particularly so for infectious and vascular diseases. In the case of cancers, the reverse was true. The Danish study addresses the relative importance of nature and nurture in the cause of disease in citizens living in a contemporary and developed society. Its findings would satisfy Garrod who anticipated them in The Inborn Factors in Disease (6). The findings imply that genes, both major and modifying, are important determinants of diseases causing premature mortality in adultage persons.

You will note in this study that, even in these sophisticated times, infectious disease continues to command attention. But here, it is the biologic determinants in the host that have become an important arbiter of the outcome of infection. Host factors are determinants both necessary and sufficient to outcome. Surely, that is a theme that was largely novel in the first century of APS but now very important for its second century. I recognize, with pleasure, that Paul Quie was one of the foresighted pediatric investigators who identified, over the past quarter century, some of the host factors causing increased susceptibility to infection.

As we begin our second century, the mapping and cloning of human genes proceeds apace. When the job is done, we will have a neo-Vesalian anatomy of humankind and, as Dr. Shapiro so effectively indicated in his talk, we will also have the knowledge and technologies to see our genes and recognize harmful mutations. Then, we will be in a better position to deal with our mendelian and multifactorial diseases. At the same time, we will understand better the determinants of physiologic homeostasis, namely the parameters of health. After all, species have been selected for successful adaptation through the evolutionary process; concern for disease and biologic deviance is only a recent and minor component of the scientific and philosophical outlooks of our particular species. I try to put the phenomenon of adaptation, health, homeostasis-call it what you will-into perspective in the last of my "visuals" (Fig. 2). Its message is fundamental to us. I imagine it lies at the root of our Society's interests, and it will carry us along into our second century.

\section{REFERENCES}

1. Scriver CR 1976 Genetics: voyage of discovery for everyman. Pediatr Res 10:865-872

2. King RC, Stansfield WD 1985 Dictionary of Genetics, 3rd ed. Oxford University Press, New York, p 437

3. Goldstein JL 1986 On the origin and prevention of PAIDS (Paralyzed Academic Investigator's Disease Syndrome). J Clin Invest 78:848-854

4. Eliot TS 1940 East Coker. Faber \& Faber, London

5. Childs B, Scriver CR 1986 Age at onset and causes of disease. Persp Biol Med 29:437-460

6. Garrod AE 1931 Inborn Factors in Disease. Oxford University Press, Oxford

7. Sorensen TI, Nielsen GG, Andersen PK, Teasdale TW 1988 Genetics and environmental influences on premature death in adult adoptees. $\mathrm{N}$ Engl $\mathrm{J}$ Med 318:727-732

8. Tufte ER 1983 The Visual Display of Quantitative Information. Graphics Press, Cheshire, CT, p 143 